\title{
PERAN WADUK GAJAH MUNGKUR TERHADAP PERTUMBUHAN SEKTOR PERTANIAN DI KABUPATEN SRAGEN
}

\author{
SUPRIHATI \\ Akademi Akuntansi Surakarta \\ Suprihati18@yahoo.com
}

\begin{abstract}
ABSTRAK
Tujuan dari penelitian ini untuk mengetahui peran Waduk Gajah Mungkur terhadap pertumbuhan sektor pertanian khususnya pada tahun irigasi teknis di Kecamatan Masaran Kabupaten Sragen dan konversi lahan pertanian ke lahan non pertanian di Kecamatan Masaran Kabupaten Sragen.

Penelitian ini merupakan penelitian deskriptif. Pengumpulan data dilakukan dengan studi kepustakaan, dokumen dan lapangan. Metode analisis digunakan adalah kualitatif.

Hasil penelitian menunjukkan bahwa peran Waduk Gajah Mungkur terhadap pertumbuhan sektor pertanian khususnya pada tahun irigasi teknik di Kecamatan Masaran Kabupaten Sragen sangat penting diantaranya mengatasi dampak dari kemarau panjang, meningkatkan produksi padi hal ini dikarenakan adanya perubahan pola tanam dalam satu tahun yaitu padi - padi - palawijo, dan adakalanya diseling dengan tanaman tebu. Dalam hasil penelitian ditemukan adanya perbedaan yang signifikan hasil produksi padi sebelum dan sesudah menggunakan irigasi teknik. Konversi lahan pertanian ke lahan non pertanian di Kecamatan Masaran Kabupaten Sragen tahun 2002 ke 2011 diketahui jenis penggunaan lahan yang meningkat cukup menonjol yaitu untuk industri menunjukkan angka $149 \mathrm{Ha}$ atau 3,38 \% dari konversi yang terjadi pada waktu tersebut, begitu juga perumahan $27,41 \%$. Sedangkan yang berkurang sawah seluas 292 Ha dan tegalan seluas 19 Ha. Dampak yang terjadi akibat konversi lahan pertanian ke non pertanian di Kecamatan Masaran Kabupaten Sragen antara lain adanya degradasi daya dukung ketahanan pangan dan pendapatan pertanian menurun dan meningkatnya kemiskinan masyarakat.
\end{abstract}

Kata kunci : Peran Waduk Gajah Mungkur, Sektor Pertanian, Konversi Lahan Pertanian ke Nonpertanian 


\section{PENDAHULUAN}

Waduk Gajah Mungkur dibangun dari tahun 1976 sampai dengan tahun 1981 berlokasi $7 \mathrm{Km}$ arah selatan Kota Wonogiri tepat dibagian hilir pertemuan kali Keduang. Luas daerah genangan lebih dari 8.800 ha dan luas daerah yang dibebaskan $90 \mathrm{~km} 2$ yang terdiri dari 51 desa di 7 Kecamatan. Pengerjaan pembangunan Waduk Gajah Mungkur dilakukan secara swakelola dengan bantuan konsultan dari Nippon Koei Co, Ltd Jepang.

Pada saat pembebasan daerah genangan ini mengorbankan 12.525 kepala keluarga $(\mathrm{KK})$ terdiri dari \pm 68.750 jiwa yang secara sukarela melakukan Program Bedhol Desa dengan bertransmigrasi ke berbagai daerah antara lain Sitiung (Propinsi Sumatera Barat), Jujuhan, Rimbo Bujang, Alai ilir, Pemenang (Propinsi Jambi), Air Lais, Sebelat, Ketahun, Ipuh (Propinsi Bengkulu), dan Panggang, Baturaja (Propinsi Sumatera Selatan)

Kondisi secara umum Waduk Gajah Mungkur adalah sebagai berikut :

1. Luas daerah tangkapan air seluas kurang lebih $1.350 \mathrm{~km} 2$

2. Waduk Gajah Mungkur memiliki 6 (enam) Daerah Aliran Sungai / DAS seluas $1.260 \mathrm{~km} 2$ yaitu Sub DAS Keduang, Tirtomoyo, Temon, Bengawan Solo Hulu, Alang, Ngunggahan;

3. $74 \%$ daerah tangkapan air masuk wilayah Kabupaten Wonogiri

4. Daerah pasang surut seluas kurang lebih $6.000 \mathrm{Ha}$, dan yang digunakan oleh masyarakat untuk budidaya pertanian seluas kurang lebih $804 \mathrm{Ha}$;

5. Luas daerah sabuk hijau atau Green Belt kurang lebih 996 Ha;

Berbagai manfaat yang diperoleh dari Pembangunan Waduk Gajah Mungkur antara lain :

1. Pengendalian banjir (flood control) sungai Bengawan Solo, dari 4000 m3/detik menjadi $400 \mathrm{~m} 3 /$ detik, sesuai kapasitas maksimum alur sungai di hilir bendungan;

2. Penyediaan air irigasi untuk kurang lebih 23.600 ha di daerah Kabupaten Klaten, Sukoharjo, Karanganyar, dan Sragen.

3. Penyediaan tenaga listrik untuk daerah Kabupaten Wonogiri dengan kapasitas maksimum 12,4 MW;

4. Obyek pariwisata disekeliling Waduk Gajah Mungkur. Obyek wisata yang paling terkenal adalah Obyek Wisata Sendang Asri Wonogiri yang menyediakan berbagai fasilitas sarana rekreasi;

5. Budidaya perikanan air tawar, terutama untuk budidaya Karamba Jala Apung ikan nila

Pembangunan pertanian di Indonesia masih dianggap sebagai bagian terpenting dari keseluruhan pembangunan ekonomi, demikian juga di Kabupaten Sragen. Hal ini semakin disadari ketika bidang pertanian telah mampu menjadi penyelamat perekonomian nasional pada saat terjadi krisis ekonomi dimana pertumbuhannya meningkat sementara pada bidang/sektor lainnya mengalami pertumbuhan 
negatif. Beberapa alasan yang mendasari pentingnya bidang pertanian antara lain (1) Potensi sumber dayanya yang besar dan beragam; (2) Pangsa pasar pendapatan nasional cukup besar; (3) Besarnya penduduk yang menggantungkan hidupnya pada bidang pertanian dan (4) Merupakan basis pertumbuhan di wilayah pedesaan. Kondisi demikian juga nampak terjadi Kabupaten Sragen dimana sebagian besar penduduknya kurang lebih sekitar 63,71 \% bergerak pada sektor pertanian (Sragen Dalam Angka 2011).

Pembangunan di sektor pertanian meliputi pertanian tanaman pangan dan holtikultura yang diarahkan pada terwujudnya perekonomian yang tangguh dan berdaya saing sehingga mampu mewujudkan suatu masyarakat yang sejahtera, melalui pengembangan sumber daya lokal, peningkatan nilai tambah dan daya saing komoditas pertanian serta pengembangan agribisnis. Sektor pertanian, utamanya pertanian tanaman pangan dan hortikultura merupakan sub sektor yang cukup berpengaruh dalam menentukan pertumbuhan ekonomi di Kabupaten Sragen.

Sektor pertanian pada tahun 2010 memberikan kontribusi terhadap total PDRB atas dasar harga konstan (ADHK) Kabupaten Sragen mencapai kenaikan 13,88 \% yang diantaranya ditopang dari sub sektor Tanaman Pangan sebesar 2,11\%, sub sektor Perkebunan sebesar 15,98 \%, serta Sub Sektor Kehutanan sebesar - 68,62 \%. Secara umum kontribusi sektor pertanian terhadap PDRB (ADHK) selama 5 (lima) hari terakhir (2006 - 2010) menunjukkan mengalami pertumbuhan cukup berarti. Pertumbuhan tersebut disebabkan oleh meningkatnya produksi beberapa komoditi Sub Sektor tanaman bahan makanan utamanya padi (Dinas Pertanian Kabupaten Sragen, 2010).

\section{PERUMUSAN MASALAH}

Berdasarkan latar belakang di atas maka yang menjadi permasalahan dalam penelitian adalah:

1. Bagaimana peran Waduk Gajah Mungkur terhadap pertumbuhan sektor pertanian khususnya pada tahun irigasi teknis di Kecamatan Masaran Kabupaten Sragen?

2. Seberapa besar konversi lahan pertanian ke lahan non pertanian di Kecamatan Masaran Kabupaten Sragen?

\section{TUJUAN PENELITIAN}

Adapun tujuan penelitian ini adalah:

1. Untuk mengetahui gambaran mengenai peran Waduk Gajah Mungkur terhadap pertumbuhan sektor pertanian khususnya pada tahun irigasi teknis di Kecamatan Masaran Kabupaten Sragen.

2. Untuk mengetahui besarnya konversi lahan pertanian ke lahan non pertanian di Kecamatan Masaran Kabupaten Sragen.

\section{TINJAUAN TEORI}

Fungsi produksi adalah hubungan fisik antara variabel yang dijelaskan (Y) dan variabel yang menjelaskan (X). Variabel yang dijelaskan biasanya berupa keluaran (output) dan variabel yang menjelaskan biasanya 
berupa masukan (input). Fungsi produksi sangat penting dalam teori produksi karena :

a. Dengan fungsi produksi, maka dapat diketahui hubungan antara faktor produksi (output) secara langsung dan hubungan tersebut dapat lebih mudah dimengerti.

b. Dengan fungsi produksi, maka dapat diketahui hubungan antara variable yang dijelaskan (dependent variable) $\mathrm{Y}$ dan variabel yang menjelaskan (independent variable) $\mathrm{X}$, serta sekaligus mengetahui hubungan antar variable penjelas. Secara matematis, hubungan ini dapat dijelaskan sebagai berikut :

$\mathrm{Y}=\mathrm{f}\left(\mathrm{x}_{1}, \mathrm{x}_{2}, \mathrm{x}_{3}, \ldots \ldots, \mathrm{x}_{\mathrm{i}}, \ldots . ., \mathrm{x}_{\mathrm{n}}\right)$

Dengan fungsi tersebut diatas, maka hubungan $\mathrm{Y}$ dan $\mathrm{X}$ dapat diketahui dan sekaligus hubungan $\mathrm{Xi}, \ldots . . \mathrm{Xn}$ dapat diketahui (Soekartawi, 1994: 35).

Menurut Mubyarto (1995: 65) fungsi produksi yaitu suatu fungsi yang menunjukkan hubungan antara hasil produksi fisik (output) dengan faktorfaktor produksi (input). Bentuk persamaan sederhana fungsi produksi ini dituliskan sebagai :

$\mathrm{Y}=\mathrm{f}\left(\mathrm{X}_{1}, \mathrm{X}_{2}, \ldots \ldots . ., \mathrm{X}_{\mathrm{n}}\right)$

Soekirno Sadono (1994: 53), menyatakan bahwa fungsi produksi adalah kaitan antara faktor-faktor produksi dan tingkat produksi yang diciptakan. Faktor-faktor produksi dikenal pula dengan istilah input dan jumlah produksi selalu juga disebut output. Fungsi produksi dinyatakan dalam bentuk rumus :

$\mathrm{Q}=\mathrm{f}(\mathrm{K}, \mathrm{L}, \mathrm{R}, \mathrm{T})$

Keterangan : $\mathrm{K}=$ jumlah stok modal

$$
\mathrm{L}=\text { jumlah tenaga kerja }
$$

$\mathrm{R}=$ kekayaan alam, dan

$\mathrm{T}=$ tingkat teknologi yang digunakan

Fungsi produksi menunjukkan bagaimana permintaan konsumen akan output atau hasil produksi menjadi permintaan produsen akan input faktor-faktor produksi.

\section{Peranan Sektor Pertanian dalam Pembangunan Ekonomi}

Peranan sektor pertanian dalam pembangunan ekonomi sangat penting karena sebagian besar anggota masyarakat di negaranegara miskin menggantungkan hidupnya pada sektor tersebut. Jika para perencana dengan sungguh-sungguh memperhatikan kesejahteraan masyarakatnya, maka satusatunya cara adalah dengan meningkatkan kesejahteraan sebagian besar anggota masyarakatnya yang hidup di sektor pertanian. Peran pertanian sebagai tulang punggung perekonomian nasional terbukti tidak hanya pada situasi normal, tetapi terlebih pada masa krisis.

Keberhasilan pembangunan pertanian memerlukan beberapa syarat atau pra kondisi yang untuk tiap daerah berbeda-beda. Pra kondisi tersebut meliputi bidang-bidang teknis, ekonomis, sosial budaya dan lain-lain. Menurut A. T Mosher ada lima syarat yang harus ada dalam pembangunan pertanian (Mubyarto, 1995: 87). Apabila salah satu syarat tersebut tidak terpenuhi maka terhentilah pembangunan pertanian, syarat tersebut adalah:

a. Adanya pasar untuk hasil-hasil usahatani.

b. Teknologi yang senantiasa selalu berkembang. 
c. Tersedianya bahan-bahan dan alat-alat produksi secara lokal.

d. Adanya perangsang produksi bagi peetani.

e. Tersedianya pengangkutan yang lancar dan kontinyu.

Menurut Todaro, Michael (2006) ada

tiga pokok dalam evolusi produksi pembangunan pertanian sebagai berikut :

a. Pertanian tradisional yang produktivitasnya rendah

b. Produk pertanian sudah mulai terjadi dimana produk pertaniansudah ada yang dijual ke sektor komersial atau pasar, tetapi pemakaian modal dan teknologi masih rendah

c. Pertanian modern yang produktivitasnya sangat tinggi yang disebabkan oleh pemakaian modal dan teknologi yang tinggi pula.

Pada tahap ini produk pertanian seluruhnya ditujukan untuk melayani keperluan pasar komersial. Modernisasi pertanian dari tahap tradisional (subsisten) menuju pertanian modern membutuhkan banyak upaya lain selain pengaturan kembali struktur ekonomi pertanian atau penerapan teknologi pertanian yang baru.

\section{Peran Waduk Gajah Mungkur terhadap Pertumbuhan Sektor Pertanian Khususnya pada Lahun Irigasi Teknik di Kecamatan Masaran Kabupaten Sragen}

Irigasi Wonogiri ini terdiri dari satu bendungan induk yang sering disebut Waduk Gajah Mungkur yang lokasinya di Wonogiri dan satu lagi bendungan pendamping sebagai penguat bendungan yang ada di daerah hilir adalah bendung Colo yang terletak di kecamatan Nguter, Kabupaten Sukoharjo. Bendung Colo terbagi menjadi dua yaitu: Saluran Induk Colo Timur dan Saluran Induk Colo Barat. Saluran Induk Colo Timur yang mengaliri air irigasi sampai ke wilayah Kabupaten Sragen.

Waduk Gajah Mungkur Wonogiri dapat mengaliri lahan seluas 23.200 Ha (Wonogiri Irigation Project) meliputi daerah di Kabupaten Sukoharjo, Klaten, Karanganyar dan Sragen. Adanya perubahan pola tanam 5 kali padi selama 2 tahun yaitu 2 kali padi 1 kali palawija per tahun, terdapat kelebihan air sebesar 105.000.000 $\mathrm{m}^{3}$, mampu mengaliri lahan seluas $10.300 \mathrm{Ha}$ (Extension Wonogiri Irigation Project) terdiri dari daerah :

a) Krisak : 1500 ha (dengan pompa)

b) Tanon : 5880 ha (dengan pompa)

c) Pengkol : 2929 ha (dengan pompa)

Subwilayah pengembangan daerah aliran anak sungai yang memotong daerah irigasi Wonogiri dan daerah bebas banjir. Mencakup pengaturan kembali sistem irigasi seluas 26.800 Ha di lembah anak sungai Bengawan Solo yang telah ada karena terpotong oleh sistem irigasi Wonogiri (Saluran Induk Colo Timur).

Hasil wawancara dengan Hadi (petugas penjaga pintu air Bendung Colo) pada tanggal 24 Januari 2012 pukul ) 09:30 wib, menjelaskan:

Irigasi Colo merupakan jaringan irigasi yang memanfaatkan air yang tertampung di Waduk Gajah Mungkur Wonogiri dengan membuat bangunan penangkap air Bendung Colo. Bendung Colo merupakan Bendung Irigasi yang terbagi menjadi dua daerah irigasi yaitu Saluran Induk Colo Timur yang mengairi 
lahan pertanian di wilayah Kabupaten Sukoharjo, Karangayar, Sragen dan sebagian kecil wilayah Ngawi. Saluran Induk Colo Barat mengairi lahan pertanian di wilayah Kabupaten Wonogiri bagian Utara, Sukoharjo bagian Selatan dan Klaten. Irigasi Bendung Colo merupakan cikal bakal jaringan irigasi tangguh dikawasan Solo Raya yang meliputi 5 kabupaten seperti kabupaten Wonogiri, Sukoharjo, Klaten, Karanganyar dan Sragen.

Pembangunan Jaringan Irigasi Bendung Colo adalah untuk menanggulangi salah satu masalah pokok yang dihadapi di wilayah Sungai Bengawan Solo Hulu, yaitu kekurangan air untuk irigasi dimusim kemarau. Volume air yang tersedia sangat terbatas, belum mampu mencukupi kebutuhan air di daerah irigasinya, meskipun sistem irigasi yang lama sudah ada, yaitu dari bendungan-bendungan kecil pada anak sungai bengawan Solo.

Bendung Colo yang terletak $\pm 13 \mathrm{~km}$ di hilir Waduk Gajah Mungkur Wonogiri,tepatnya di Desa Pengkol, kecamatan Nguter, Kabupaten Sukoharjo, dengan luas daerah irigasi keseluruhan \pm 23.200 Ha yang mencakup Saluran Induk Colo Timur dan Saluran Induk Colo barat.

Hasil wawancara dengan Hadi (petugas penjaga pintu air Bendung Colo) pada tanggal 24 Januari 2012 pukul ) 09:30 wib, menjelaskan:

Bendung Colo dibagi menjadi dua aliran irigasi yaitu Saluran Induk Colo Timur (daerah irigasi di Kabupaten Sukoharjo, Karanganyar dan Sragen) dan Saluran Induk Colo Barat (daerah irigasi di Kabupaten Wonogiri, Sukoharjo dan Klaten). Saluran Induk Colo Timur dirasa bisa menjadi solusi bagi petani di Kabupaten Sragen untuk mencukupi kebutuhan air bagi sawah-sawah mereka yang pada waktu itu hanya berupa lahan kering dan hanya mengandalkan air dari tadah hujan dan sedikit air irigasi dari sungai alami.

Segi manfaat yang diperoleh dari Bendung Colo kepada petani-petani yang berada di daerah hilir sebagai berikut :

1. Produksi padi dan palawija untuk kebutuhan pokok pertahun akan meningkat, berarti peningkatan tarap hidup petani

2. Jalan dan jembatan inspeksinya dapat membantu memperlancar pengakutan hasil pertanian, terutama padi dan palawija.

3. Berfungsinya drainasi secara optimal diharapkan dapat mengurangi banjir, sehingga meningkatkan kualitas hidup.

4. Menaikan tinggi muka air tanah, sehingga sumur-sumur penduduk di sekitar saluran induk terjamin airnya, sehingga tidak mengalami kekeringan.

Irigasi Colo Timur adalah salah satu jaringan irigasi terletak di wilayah Sungai Bengawan Solo Hulu, merupakan bagian dari Rencana Induk pengembangan Wilayah Sungai Bengawan Solo. Terbagi di tiga wilayah kabupaten, yaitu : 
ISSN :

Daerah Irigasi Bendung Colo Timur

\begin{tabular}{|c|l|c|}
\hline No. & \multicolumn{1}{|c|}{ Wilayah Irigasi } & $\begin{array}{c}\text { Luas } \\
(\mathrm{Ha})\end{array}$ \\
\hline 1. & Kabupaten Sukoharjo & $8.253,30$ \\
2. & Kabupaten Karanganyar & $2.664,10$ \\
3. & Kabupaten Sragen & $8.862,60$ \\
\hline
\end{tabular}

Sumber: Arsip Bendung Colo, 2010.

Semula rencana yang dikerjakan adalah pembangunan jaringan irigasi seluas 19.600 ha, tetapi dalam pelaksanaan berkembang menjadi 19.780 ha. Dari data tersebut BPS Kabupaten Sragen mempunyai luas daerah irigasi Saluran Induk Colo Timur seluas $8.862,60$ ha, termasuk wilayah kecamatan Masaran seluas 4.404 ha. Lahan pertanian di Kecamatan Masaran seluas 2.321 ha yang mendapat oncoran irigasi dari Saluran Induk Colo Timur.

Proyek irigasi Bendung Colo Timur dibentuk dengan maksud melaksanakan pembuatan jaringan irigasi baru, menata dan merehabilitasi jaringan irigasi yang sudah ada. Tujuan yang hendak dicapai adalah memanfaatkan sumber daya air semaksimal mungkin dan untuk meningkatkan produksi pangan, terutama padi dan palawija. Irigasi ini juga bertujuan untuk mencapai swasembada beras dan diversifikasi bahan pangan serta menunjang peningkatan produksi tebu pada waktu itu. Seperti yang sudah diketahui di daerah-daerah di wilayah Kabupaten Sukoharjo, Karanganyar dan Sragen sebelum ada jaringan irigasi ini, hanya mengandalkan sawah tadah hujan saja, seperti petani yang ada di wilayah Kabupaten Sragen.Dengan demikian peran Waduk Gajah Mungkur pada sektor pertanian di Kecamatan Masaran Kabupaten Sragen adalah:

1. Mengatasi kekeringan

Musim kemarau yang kini melanda beberapa daerah di tanah air, mengakibatkan sulitnya pengadaan air. Untuk itu, pertama harus diantisipasi dengan mengendalikan sumber atau kapasitas supply. Seperti kemarau panjang yang melanda tahun 2011 mengakibatkan kerugian besar dalam sektor pertanian. Khususnya bagi petani padi yang membutuhkan kapasitas air yang cukup.

Peran waduk sangat vital untuk pertanian, terutama pada saat musim tanam ke dua dan seterusnya. Tersedianya air untuk irigasi merupakan faktor penentu dalam produksi beras sehingga kebutuhan pangan yang diharapkan dapat terpenuhi. Saat ini lebih dari 20 persen irigasi rusak sehingga bisa mengganggu peningkatan produksi pangan (Solopos, 22 September 2011).

2. Meningkatkan produksi padi

Perubahan rencana pola tanam 5 (lima) kali padi dalam 2 (dua) tahun menjadi padi-padi-palawija pertahun, maka terdapat kelebihan cadangan air 
di Waduk Gajah Mungkur Wonogiri. Seperti pernyataan beberapa petani di Kecamatan Masaran, sebagai berikut:

Air waduk sangat membantu penyediaan air khususnya pada sawah tadah hujan, karena pada tanah jenis ini biasanya mudah terjadi banjir pada waktu musim hujan dan terjadi kekeringan pada musim kemarau. Waduk Gajah Mungkur telah memberikan andil yang luar biasa terkait pengaturan ketersediaan air sehingga sampai dengan bulan september (pada saat dilakukan penelitian) debet air yang tersedia masih mampu untuk memberikan jatah pengairan bagi daerah persawahan yang berada dalam sistem irigasinya (Pernyataan Bapak Lasdan, Ketua Kelompok Tani Gemah Ripah dari Desa Pilang, tanggal 25 Januari 2012, jam 16.00 wib).Irigasi dari Waduk Gajah Mungkur sangat membantu produkti tani di Desa Krebet, yang sebelumnya hanya menunggu datangnya hujan saja bisa bercocok tanam, sekarang tidak lagi. Hasilnya pun lebih banyak yang sebelumnya 2.524 ton setelah ada irigasi teknik dari WGM mencapai 3000 ton lebih per tahun (Pernyataan Bapak Wikarto, Ketua Kelompok Tani Juru Martani III dari Desa Krebet, tanggal 23 Januari 2012, jam 16.00 wib).

Dengan adanya irigasi teknikdari WGM ini petani di Desa Sidodadi ada perubahan pola tanam 5 kali padi selama 2 tahun menjadi 2 kali padi 1 kali palawija per tahun (Pernyataan Bapak Senen, Ketua
Kelompok Tani Sumber Rejeki dari Desa Sidodadi, tanggal 26 Januari 2012, jam 16.00 wib).

Dengan demikian dapat disimpulkan bahwa telah terjadi peningkatan produksi padi setelah mendapatkan irigasi teknik dari Waduk Gajah Mungkur. Perubahan ekologi berdampak pada pola tanam yang dikembangan masyarakat Kecamatan Masaran, berawal dari dua kali masa panen per tahun menjadi tiga kali masa panen. Hubungan sebab akibat ini juga berdampak pada penghasilan tiap petani yang mengalami peningkatan. Pertanian sawah irigasi teknik yang dilakukan oleh masyarakat Kecamatan Masaran dalam perkembanganya mampu membawa suatu perubahan dibidang ekonomi ke arah yang lebih baik. Hal ini dapat terjadi karena penghasilan yang diperoleh oleh petani tidak kalah dengan para perantau yang mengadu nasib ke kota-kota besar bahkan bisa melampaui angka Upah Minimum Regional (UMR) Kabupaten Sragen, sehingga keberadaan sawah dengan irigasi teknik ini mampu meningkatkan taraf hidup keluarga maupun untuk kebutuhan masa depan para petani. Perubahan yang terjadi meliputi perubahan pola tanam yang dulu hanya dua kali masa tanam, tapi sekarang menjadi tiga masa tanam dan dulu belum mengenal sistem pola tanam dan rencana tata tanam. Hasil padi sawah di Kecamatan Masaran sebelum dan sesudah menggunakann irigasi teknik Waduk Gajah Mungkur Wonogiri sebagai berikut:

Perkembangan Hasil Padi di Kecamatan Masaran

\begin{tabular}{|l|c|c|c|c|}
\hline \multirow{2}{*}{ No. } & \multicolumn{2}{|c|}{ Sebelum } & \multicolumn{2}{c|}{ Sesudah } \\
\cline { 2 - 5 } & Tahun & Hasil (Ton) & Tahun & Hasil (Ton) \\
\hline
\end{tabular}




\begin{tabular}{|c|l|l|l|l|}
\hline 1 & 1980 & 8.712 & 2002 & 38.061 \\
2 & 1981 & 9.705 & 2003 & 38.164 \\
3 & 1982 & 7.763 & 2004 & 37.948 \\
4 & 1983 & 7.260 & 2005 & 40.306 \\
5 & 1984 & 8.201 & 2006 & 44.436 \\
6 & 1985 & 7.767 & 2007 & 42.080 \\
7 & 1986 & 8.440 & 2008 & 44.281 \\
8 & 1987 & 9.578 & 2009 & 40.834 \\
9 & 1988 & 7.146 & 2010 & 38.720 \\
10 & 1989 & 8.247 & 2011 & 30.384 \\
\hline
\end{tabular}

Sumber: Dinas Pertanian Kab. Sragen dan BPS Kab. Sragen, 2011.

Tabel di atas dapat dilihat perbandingan antara produkti padi sebelum menggunakan irigasi teknis dan sesudah menggunakan irigasi teknis terdapat perbedaan yang sangat signifikan yaitu 23,86 terbukti nilai signifikansi lebih dari $5 \%$. Dapat dipertegas kembali bahwa melihat perolehan hasil padi di kecamatan Masaran di atas maka peran irigasi teknis sangat penting dalam pemenuhan produksi pangan di sektor pertanian.

3. Merubah pola tanam

Tanaman padi pada umumnya membutuhkan air untuk proses pertumbuhannya dari sejak persemaian sampai proses pembentukan pati butir padi, tetapi kebutuhan air tersebut mempunyai fase-fase tertentu yang dibutuhkan oleh tanaman padi. Kebutuhan air antara jenis padi berbeda, padi sawah lebih banyak membutuhkan air dari pada padi gogo atau padi lahan kering.

Penggunaan air irigasi dapat dilakukan secara efesien dan efektif sesuai dengan volume air yang ada dapat dilakukan antara lain; a) pemeliharaan bendungan, saluran primer, sekunder dan tertier, dengan pemeliharaan bendungan dan saluran tersebut maka air yang ada benar-benar dapat dialirkan ke persawahan para petani yang menanam padi, b) pemasukan air ke sawah sesuai kebutuhan, air yang dialirkan ke persawahan para petani harus disesuaikan debitnya sesuai kebutuhan padi yang sedang ditanam, pada saat air dibutuhkan padi misalnya pada persemaian dan pertumbuhan, sedangkan pada saat musim hujan dan pengeringan butir malai maka debit air yang dimasukkan ke sawah dikurangi/dibatasi, c) pengolahan tanah, pada saat pengolahan tanah ada masa pelapukan/pengeringan tanah maka saat itu pemasukan air ke sawah diberhentikan sehingga air dapat digunakan ke lahan sawah lainnya yang dibutuhkan petani.

Pengaturan pola tata tanam adalah kegiatan mengatur awal masa tanam, jenis tanaman dan varitas tanaman dalam suatu tabel perhitungan Tujuan utama dari penyusunan pola tanam adalah untuk mendapatkan besaran kebutuhan air irigasi pada musim kemarau sekecil mungkin. Di dalam penyusunan pola tata tanam dilakukan simulasi penentuan awal tanam. Misalnya alternatif pertama, jika awal tanam padi pada awal bulan Oktober, alternatif kedua, jika awal tanam padi pada awal bulan 
Nopember begitu seterusnya hingga alternatif ke duabelas yang awal tanam padi dimulai pada awal September. Dari keduabelas alternatif tadi dipilih alternatif yang "kebutuhan air irigasi" nya paling rendah (Dinas Pertanian Kabupaten Sragen, 2011).

Penyusunan pola tata tanam didasarkan pada tengah bulanan atau tiap 15 harian, artinya besaran-besaran yang ikut di dalam perhitungan (seperti besaran Eto, Pd, P\&I) dihitung selama 15 harian (bukan bulanan atau bukan harian) yaitu ditandai dengan adanya angka 1 dan 2 (Dinas Pertanian Kabupaten Sragen, 2011).

Penyusunan pola tata tanam dilakukan selama 1 tahun dengan disisipi 1 musim untuk tanaman palawija (tanaman jagung, kacang, kedele, singkong atau ubi), misalnya pola tata tanam : padi pertama, sesudah padi pertama maka dilanjutkan dengan pengolahan tanah untuk persiapan tanam padi kedua, sesudah padi kedua panen, maka lahan ditanami dengan palawija, tidak dengan padi lagi. Hal ini dimaksudkan untuk memutus rantai serangan hama pada tanaman padi serta memberi kesempatan tanah untuk memulihkan unsurunsur haranya setelah berturut-turut ditanami padi.

Dari analisis pemanfaatan waduk sebagai sarana irigasi, dapat ditarik beberapa hasil analisis antara lain:

1. Air waduk sangat membantu penyediaan air khususnya pada sawah tadah hujan, karena pada tanah jenis ini biasanya mudah terjadi banjir pada waktu musim hujan dan terjadi kekeringan pada musim kemarau. Waduk Gajah Mungkur telah memberikan andil yang besar terkait pengaturan ketersediaan air sehingga pada puncak kemarau debet air yang tersedia masih mampu untuk menyediakan air pada sistem irigasinya.

2. Operasional waduk Gajah Mungkur merupakan tugas dan tanggung jawab bersama, dan dalam operasionalnya diatur dengan dasar keperluan daerah irigasi yang mendapatkan jatah air dengan mempertimbangkan kapasitas air tersedia, luas daerah irigasi yang akan ditanami dan pola tanam sebagai inflow kedalam waduk

3. Fungsi Waduk Gajah Mungkur sebagai sarana irigasi sangat menonjol dan berpengaruh terhadap tata guna lahan. Hal tersebut terlihat pada peta tata kesesuaian lahan dalam Rencana Tata Ruang Wilayah Kabupaten Sragen dimana pada daerah yang merupakan jaringan irigasi termasuk daerah yang sangat sesuai untuk tanaman lahan basah.

4. Agar operasionallisasi waduk dapat berjalan dengan baik. Perlu dilakukan pemeliharaan waduk yang dimaksudkan untuk menjaga kondisi waduk tetap baik sehingga dapat dioperasikan sesuai dengan fungsinya dan juga untuk menjaga keamanan dari waduk itu sendiri.

\section{Konversi Lahan Pertanian Ke Lahan Non Pertanian di Kecamatan Masaran Kabupaten Sragen}

Mengkaji permasalahan tentang fungsi lahan sawah terkait erat dengan mengkaji masalah pangan, khususnya beras. Sebagian dari lahan sawah yang terkonversi itu beralih fungsi menjadi lahan pertanian lahan kering, dan sebagian lainnya beralih fungsi ke penggunaan nonpertanian untuk memenuhi kebutuhan 
pemukiman, pengembangan industri, jasa, dan lain sebagainya.

Menurut Bapak Ir. Haryoto AW, MM selaku Kepala Dinas Pertanian Kabupaten Sragen (Tanggal 30 Januari 2012, jam 13.00 wib) menyatakan menurunnya pertumbuhan produksi padi pada Pelita VI terjadi sebagai akibat dari menurunnya produktivitas maupun areal panen. Produktivitas agregat tersebut akibat dari: (a) kegagalan mempertahankan produktivitas yang pernah dicapai pada periode sebelumnya pada lahan-lahan sawah yang ada, (b) berkurangnya proporsi lahan sawah yang produktivitasnya tinggi sebagai akibat alih fungsi lahan sawah ke nonsawah, (c) kombinasi (a) dan (b).

Butir (a) terjadi karena mutu intensifikasi mengalami kemandegan. Sementara itu sebagai akibat dari pemupukan intensif secara berkesinambungan tanpa adanya tindakan-tindakan nyata dalam pengembalian bahan-bahan organik ke lahan sawah, maka keseimbangan hara dalam tanah memburuk. Butir (b) terjadi akibat tidak efektifnya kebijakan pengendalian konversi lahan sawah. Terutama di wilayah sekitar urban, perluasan pengembangan pemukiman dan kawasan industri/pariwisata telah menelan lahan-lahan pertanian tanpa pilih kasih. Bukan hanya lahan pertanian yang kurang produktif saja yang dikonversi, tetapi juga lahan-lahan sawah produktif. Butir (c) merupakan dampak tak langsung dari butir (b). Ternyata, hasil penelitian menunjukkan bahwa produktivitas persawahan di sekitar lahan sawah yang terkonversi cenderung menurun. Penyebabnya adalah rusaknya jaringan irigasi, pencemaran, rusaknya keseimbangan ekologi sawah.
Kebutuhan lahan untuk kegiatan nonpertanian cenderung terus meningkat seiring dengan peningkatan jumlah penduduk dan perkembangan struktur perekonomian. Alih fungsi lahan pertanian sulit dihindari akibat kecenderungan tersebut. Beberapa kasus menunjukkan jika di suatu lokasi terjadi alih fungsi lahan, maka dalam waktu yang tidak lama lahan di sekitarnya juga beralih fungsi secara progresif.

Pola konversi lahan dapat ditinjau dari beberapa aspek. Dilihat dari pelaku konversi, dapat dibedakan menjadi dua. Pertama, alih fungsi secara langsung oleh pemilik lahan yang bersangkutan. Lazimnya, motif tindakan ada 3: (a) untuk pemenuhan kebutuhan akan tempat tinggal, (b) dalam rangka meningkatkan pendapatan melalui alih usaha, (c) kombinasi dari (a) dan (b) seperti misalnya untuk membangun rumah tinggal yang sekaligus dijadikan tempat usaha. Pola konversi seperti ini terjadi di sembarang tempat, kecil-kecil dan tersebar. Dampak konversi terhadap eksistensi lahan sawah sekitarnya baru significant untuk jangka waktu lama. Kedua, alih fungsi yang diawali dengan alih penguasaan. Pemilik menjual kepada pihak lain yang akan memanfaatkannya untuk usaha nonsawah atau kepada makelar. Secara empiris, alih fungsi lahan melalui cara ini terjadi dalam hamparan yang lebih luas, terkonsentrasi dan umumnya berkorelasi positif dengan proses urbanisasi (pengkotaan). Dampak konversi terhadap eksistensi lahan sawah sekitarnya berlangsung cepat dan nyata. 
Masih menurut Beliau Ir. Haryoto AW, MM (Tanggal 30 Januari 2012, jam 13.00 wib). jika pola konversi lahan ditinjau menurut tipe lahan sawah yang terkonversi dan fungsi pemanfaatan selanjutnya, tampak adanya fenomena yang menunjukkan bahwa eksistensi kualitas irigasi tampaknya tak dihargai. Di Kabupaten Sragen khususnya lebih dari $15 \%$ lahan sawah beririgasi teknis yang terkonversi adalah untuk pengembangan pemukiman, industri, dan jalan raya. Pada lahan sawah irigasi sederhana maupun tadah hujan, terjadi berbagai variasi akan tetapi alih fungsi untuk penggunaan usaha tani nonpadi pangsanya justru lebih besar jika dibandingkan dengan fenomena yang terjadi pada lahan sawah beririgasi teknis/semiteknis.

Di Kecamatan masaran yang memiliki luas wilayah $4.404 \mathrm{Ha}$ sebagian besar terdiri dari sawah yaitu $66,44 \%$. Penggunaan lahan kedua yang terbesar adalah perumahan/pekarangan yaitu 27,41 $\%$ dan untuk lebih jelasnya dapat dilihat perbandingan konversi lahan tahun 2002 ke 2011 yang tercantum dalam Tabel dibawah ini.

Konversi Penggunaan Lahan Kecamatan Masaran

\begin{tabular}{|c|c|c|c|c|c|c|}
\hline \multirow[b]{2}{*}{ No. } & \multirow[b]{2}{*}{$\begin{array}{c}\text { Jenis Penggunaan } \\
\text { Lahan }\end{array}$} & \multicolumn{4}{|c|}{ Penggunaan Lahan } & \multirow[b]{2}{*}{$\begin{array}{c}(-/+) \\
\mathrm{Ha}\end{array}$} \\
\hline & & $\begin{array}{l}2002 \\
(\mathrm{Ha})\end{array}$ & $\%$ & $\begin{array}{l}2011 \\
(\mathrm{Ha})\end{array}$ & $\%$ & \\
\hline 1. & Perumahan/pekarangan & 1033 & 23,46 & 1207 & 27,41 & 194 \\
\hline 2. & Industri & 52 & 1,18 & 149 & 3,38 & 117 \\
\hline 3. & Sawah & 3178 & 72,16 & 2926 & 66,44 & -292 \\
\hline 4. & Tegalan & 141 & 3,20 & 122 & 2,77 & -19 \\
\hline & Jumlah & 4404 & 100,00 & 4404 & 100,00 & \\
\hline
\end{tabular}

Sumber: Sragen dalam Angka, 2011.

Jenis penggunaan lahan yang meningkat cukup menonjol yaitu untuk industri menunjukkan angka $149 \mathrm{Ha}$ atau $3,38 \%$ dari konversi yang terjadi pada waktu tersebut, begitu juga perumahan $27,41 \%$. Sedangkan yang berkurang sawah seluas $292 \mathrm{Ha}$ dan tegalan seluas $19 \mathrm{Ha}$.

Dampak yang terjadi akibat konversi lahan pertanian ke non pertanian di Kecamatan Masaran Kabupaten Sragen antara lain:

1. Degradasi daya dukung ketahanan pangan
Penurunan produksi yang disebabkan oleh serangan hama, penyakit, kekeringan ataupun banjir berbeda dengan berkurangnya produksi padi akibat konversi lahan sawah adalah bersifat permanen. Sekali lahan sawah berubah fungsi, berarti tak lagi lahan tersebut dapat menjadi sawah kembali. Hampir tidak pernah dijumpai bahwa lahan sawah yang telah beralih fungsi menjadi nonsawah (apalagi untuk peruntukan nonpertanian) kemudian berubah kembali menjadi sawah. 
Fenomena demikian mempunyai implikasi yang serius terhadap perhitungan mengenai dampak negatif konversi lahan sawah terhadap produksi pangan.

Sangat logis bahwa semakin tinggi produktivitas lahan sawah yang terkonversi, semakin tinggi pula kerugian yang terjadi. Berdasarkan data empiris selama ini, kerugian itu berupa hilangnya kesempatan kapasitas untuk memproduksi padi antara 4,5 - 12,5 ton/ha/tahun, tergantung pada kualitas lahan sawah yang bersangkutan (Gambar IV.1). Kualitas dalam konteks ini menyangkut tingkat ketersediaan air dan kesuburan tanah. Untuk lahan sawah beririgasi teknis pada umumnya dapat ditanami padi dua kali plus palawija/sayuran sekali. Sedangkan untuk lahan tadah hujan, selain hanya dapat ditanami padi sekali setahun, pada umumnya produktivitasnyapun lebih rendah dari lahan sawah beririgasi teknis. Angka-angka tersebut adalah kerugian yang sifatnya langsung. Selain itu, ada pula kerugian yang sifatnya tidak langsung, yakni turunnya produktivitas lahan sawah di sekitarnya sebagai akibat degradasi ekologi lahan sawah.

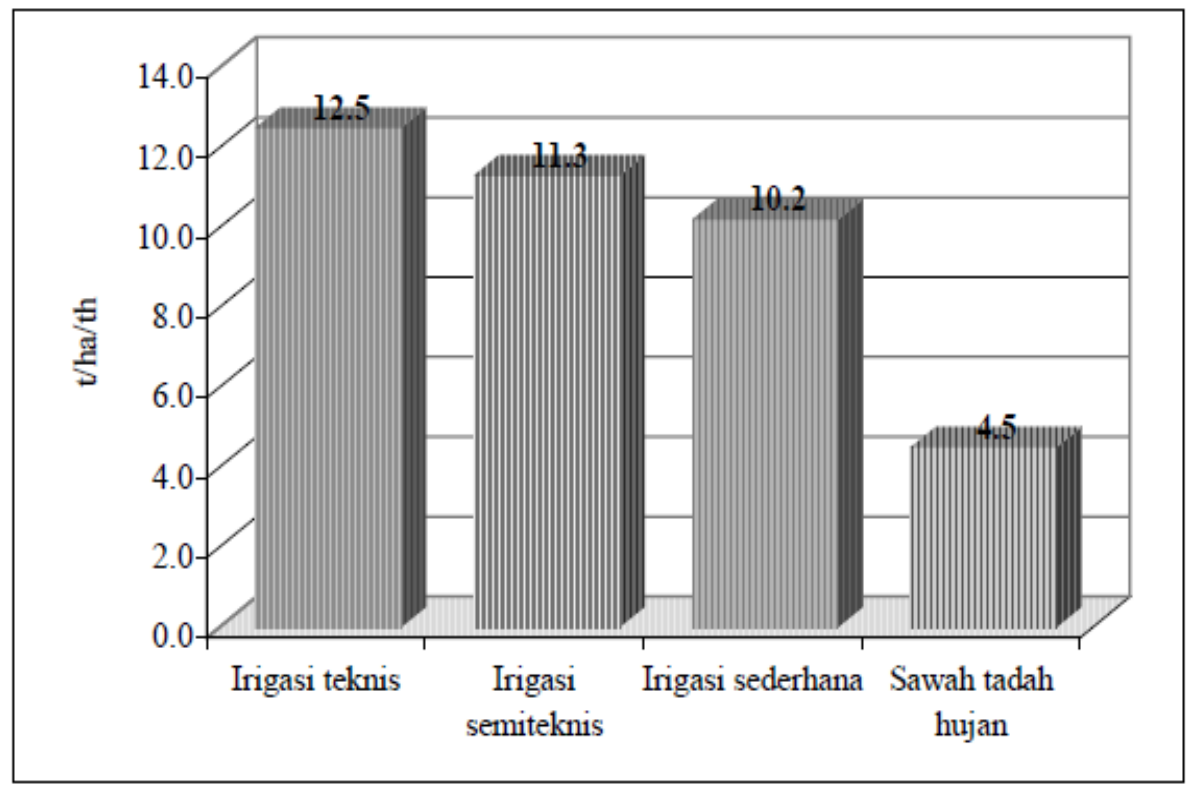

Rata-rata Produktivitas Lahan Sawah sebelum Terkonversi (t/ha/th)

Sumber: Dinas Pertanian Kabupaten Sragen, 2010.

Seperti yang diterangkan Bapak Tri Warsono selaku Sekretaris Camat Masaran ada dua faktor yang menjadi penyebab terjadinya alih fungsi lahan sawah ke lahan nonsawah. Pertama, sejalan dengan pembangunan kawasan perumahan atau industri di suatu lokasi alih fungsi lahan, maka aksesibilitas di lokasi tersebut menjadi semakin kondusif untuk pengembangan industri dan pemukiman yang akhirnya mendorong meningkatnya permintaan lahan oleh investor lain atau spekulan tanah sehingga harga lahan di sekitarnya meningkat. 
Kedua, peningkatan harga lahan selanjutnya dapat merangsang petani lain di sekitarnya untuk menjual lahan. Biasanya pelaku pembelian tanah biasanya bukan penduduk setempat, sehingga mengakibatkan terbentuknya lahan-lahan guntai yang secara umum rentan terhadap proses alih fungsi lahan.

Alih fungsi lahan sawah ke penggunaan nonpertanian dapat berdampak terhadap turunnya produksi pertanian, serta akan berdampak pada dimensi yang lebih luas dimana berkaitan dengan aspek-aspek perubahan orientasi ekonomi, sosial, budaya, dan politik masyarakat.

Berdasarkan penelitian yang dilakukan oleh Rahmanto, dkk (2002), ditinjau dari aspek produksi, kerugian akibat alih fungsi lahan sawah di Jawa selama kurun waktu 18 tahun (1981-1998) diperkirakan telah menyebabkan hilangnya produksi beras sekitar 1,7 juta ton/tahun atau sebanding dengan jumlah impor beras tahun 1984-1997 yang berkisar antara 1,52,5 juta ton/tahun.

Alih fungsi lahan sawah juga menyebabkan hilangnya kesempatan petani memperoleh pendapatan dari usahataninya. Dalam penelitian Rahmanto, dkk (2002) juga menyebutkan, hilangnya pendapatan dari usahatani sawah di Jawa Barat dan Jawa Timur mencapai Rp 1,5 - Rp 2 juta/Ha/tahun dan kehilangan kesempatan kerja mencapai kisaran 300 - $480 \quad \mathrm{HOK} / \mathrm{Ha} /$ tahun. Perolehan pendapatan pengusaha traktor dan penggilingan padi juga ikut berkurang, masing-masing sebesar Rp 46 - Rp 91 ribu dan Rp 45 - Rp 114 $\mathrm{ribu} / \mathrm{Ha} /$ tahun akibat terjadinya alih fungsi lahan.
Menurut penelitian yang dilakukan oleh Widjanarko, dkk (2006) terkonsentrasinya pembangunan perumahan dan industri di Pulau Jawa, di satu sisi menambah terbukanya lapangan kerja di sektor nonpertanian seperti jasa konstruksi, dan industri, akan tetapi juga menimbulkan dampak negatif yang kurang menguntungkan. Dampak negatif tersebut antara lain :

a. Berkurangnya luas sawah yang mengakibatkan turunnya produksi padi, yang mengganggu tercapainya swasembada pangan dan timbulnya kerawanan pangan serta mengakibatkan bergesernya lapangan kerja dari sektor pertanian ke nonpertanian. Apabila tenaga kerja tidak terserap seluruhnya akan meningkatkan angka pengangguran.

b. Investasi pemerintah dalam pengadaan prasarana dan sarana pengairan menjadi tidak optimal pemanfaatannya.

c. Kegagalan investor dalam melaksanakan pembangunan perumahan maupun industri, sebagai dampak krisis ekonomi, atau karena kesalahan perhitungan mengakibatkan tidak termanfaatkannya tanah yang telah diperoleh, sehingga meningkatkan luas tanah tidur yang pada gilirannya juga menimbulkan konflik sosial seperti penjarahan tanah.

d. Berkurangnya ekosistem sawah terutama di jalur pantai utara Pulau Jawa sedangkan pencetakan sawah baru yang sangat besar biayanya di luar Pulau Jawa seperti di Kalimantan Tengah, tidak menunjukkan dampak positif.

Seperti pernyataan Bapak Tri Warsono selaku Sekcam Masaran pada tanggal 30 Januari 
2012 bahwa alih fungsi lahan pertanian bukan hanya sekedar memberi dampak negatif seperti mengurangi produksi beras, akan tetapi dapat pula membawa dampak positif terhadap ketersediaan lapangan kerja baru bagi sejumlah petani terutama buruh tani yang terkena oleh alih fungsi tersebut serta meningkatkan pertumbuhan ekonomi.

Proses alih fungsi lahan pertanian pada tingkat mikro dapat dilakukan oleh petani sendiri atau dilakukan pihak lain. Alih fungsi lahan yang dilakukan oleh pihak lain secara umum memiliki dampak yang lebih besar terhadap penurunan kapasitas produksi pangan karena proses alih fungsi lahan tersebut biasanya mencakup hamparan lahan yang cukup luas, terutama ditujukan untuk pembangunan kawasan perumahan. Alih fungsi lahan yang dilakukan oleh pihak lain tersebut biasanya berlangsung melalui pelepasan hak pemilikan lahan petani kepada pihak lain yang kemudian diikuti dengan, pemanfaatan lahan tersebut untuk kegiatan non pertanian. Dampak alih fungsi lahan pertanian terhadap masalah pengadaan pangan pada dasarnya terjadi pada tahap kedua. Oleh karena itu pengendalian pemanfaatan lahan untuk kepentingan pengadaan pangan pada dasarnya dapat ditempuh melalui dua pendekatan yaitu:

a. Mengendalikan pelepasan hak pemilikan lahan petani kepada pihak lain, dan

b. Mengendalikan dampak alih fungsi lahan tanaman pangan tersebut terhadap keseimbangan pengadaan pangan.

Berdasarkan uraian di atas mengenai degradasi ketahanan pangan dapat penulis ambil kasimpulan, bahwa terdapat empat faktor yang menyebabkan dampak konversi lahan pertanian terhadap masalah pangan tidak dapat segera dipulihkan, yaitu:

Pertama, lahan pertanian yang sudah dikonversi ke non pertanian yang sifatnya permanen atau tidak pernah berubah kembali menjadi lahan pertanian memiliki sifat irreversible. Hal ini karena dengan berubahnya lahan pertanian menjadi kawasan industri, perumahan, perdagangan, maka nilai lahan akan naik berlipat ganda. Fenomena ini ditunjukkan oleh perbandingan antara sewa lahan pertanian dibanding nilai sewa lahan nonpertanian yang sangat besar.

Kedua, upaya pencetakan sawah baru dalam rangka pemulihan produksi pangan pada kondisi semula membutuhkan jangka waktu yang sangat panjang.

Ketiga, sumberdaya lahan yang dapat dijadikan sawah semakin terbatas. Disamping itu anggaran pemerintah juga semakin sulit, padahal sebagian besar kegiatan pencetakan sawah didukung dengan dana pemerintah. Keterbatasan sumberdaya lahan dan anggaran pemerintah, menyebabkan upaya pencetakan sawah dan rehabilitasi jaringan irigasi untuk menetralisir peluang produksi padi yang hilang akibat konversi lahan tidak mudah diwujudkan.

Keempat, untuk dapat mengantisipasi peluang produksi yang hilang tersebut, salah satu cara yang dapat ditempuh adalah dengan meningkatkan produktivitas usahatani padi sawah. Namun akibat stagnasi inovasi teknologi pada akhir-akhir ini, upaya tersebut semakin sulit diwujudkan.

2. Pendapatan pertanian menurun dan meningkatnya kemiskinan masyarakat 
Sudah menjadi cerita klasik bahwa mayoritas pelaku usaha tani padi adalah masyarakat pedesaan berikut segala atributnya (miskin, berpendidikan rendah, lahan usaha taninya sempit). Cerita klasik itu adalah fakta dan tendensi semakin kecilnya rata-rata luas sawah garapan tak dapat dicegah. Terutama di pedesaan dengan agroekosistem sawah, proses itu berjalan sangat cepat .

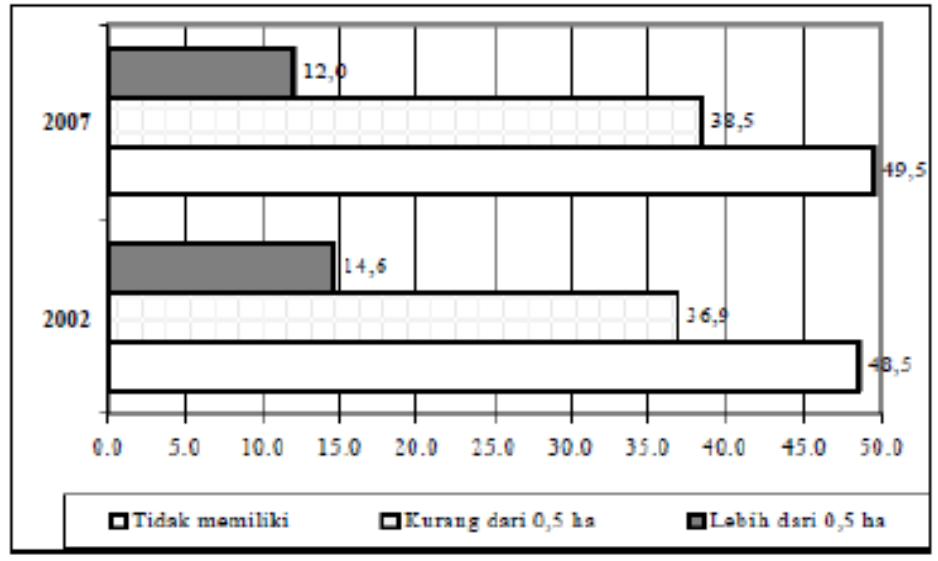

Sebaran Rumah Tangga menurut Luas Pemilikan Lahan di Kecamatan Masaran

Rata-rata pendapatan tani padi per ha per musim. Berpatokan pada data tahun 2007, penerimaan bersih (pendapatan) usaha tani padi adalah sekitar Rp 4,3 juta/ha/musim dari nilai output sekitar Rp 6,3 juta. Total biaya adalah sekitar Rp 2,0 juta, dimana sekitar 45\% dari biaya itu adalah ongkos tenaga kerja. Artinya, per ha lahan sawah yang terkonversi menyebabkan hilangnya kesempatan petani memperoleh pendapatan sebesar Rp 2 juta dan kelompok buruh tani sebesar Rp. 900.000/musim.

Berbagai kebijakan yang berkaitan dengan masalah pengendalian alih fungsi lahan sawah sudah banyak dibuat. Akan tetapi, hingga kini implementasinya belum berhasil diwujudkan secara optimal. Menurut Bapak Tri Warsono hal ini antara lain karena kurangnya dukungan data dan minimnya sikap proaktif yang memadai ke arah pengendalian alih fungsi lahan sawah tersebut. Terdapat tiga kendala mendasar yang menjadi alasan mengapa peraturan pengendalian alih fungsi lahan sulit terlaksana, yaitu :

1. Kendala Koordinasi Kebijakan. Di satu sisi pemerintah berupaya melarang terjadinya alih fungsi lahan, tetapi di sisi lain justru mendorong terjadinya alih fungsi lahan tersebut melalui kebijakan pertumbuhan industri/ manufaktur dan sektor nonpertanian lainnya yang dalam kenyataannya menggunakan tanah pertanian.

2. Kendala Pelaksanaan Kebijakan. Peraturanperaturan pengendaliah alih fungsi lahan baru menyebutkan ketentuan yang dikenakan terhadap perusahaan-perusahaan atau badan hukum yang akan menggunakan lahan dan atau akan merubah lahan pertanian ke nonpertanian. Oleh karena itu, 
perubahan penggunaan lahan sawah ke nonpertanian yang dilakukan secara individual/perorangan belum tersentuh oleh peraturan-peraturan tersebut, dimana perubahan lahan yang dilakukan secara individual diperkirakan sangat luas.

3. Kendala Konsistensi Perencanaan. RTRW yang kemudian dilanjutkan dengan mekanisme pemberian izin lokasi, merupakan instrumen utama dalam pengendalian untuk mencegah terjadinya alih fungsi lahan sawah beririgasi teknis. Namun dalam kenyataannya, banyak RTRW yang justru merencanakan untuk mengalih fungsikan lahan sawah beririgasi teknis menjadi nonpertanian.

Menurut penelitian yang dilakukan oleh Widjanarko, dkk (2006) dalam konteks pembangunan di Pulau Jawa, jumlah keluarga atau rumah tangga yang hidup dari sektor nonpertanian mencapai $100 \%$. Beberapa faktor penting yang berpengaruh pada perubahan pola pemanfaatan lahan pertanian di Pulau Jawa yaitu faktor privatisasi pembangunan kawasan industri, pembangunan pemukiman skala besar dan kota baru, serta deregulasi investasi dan kemudahan perizinan. Tiga kebijakan nasional yang berpengaruh langsung terhadap alih fungsi lahan pertanian ke nonpertanian ialah:

1. Kebijakan privatisasi pembangunan kawasan industri sesuai Keputusan Presiden Nomor 53 tahun 1989 yang telah memberikan keleluasaan kepada pihak swasta untuk melakukan investasi dalam pembangunan kawasan industri dan memilih lokasinya sesuai dengan mekanisme pasar. Dampak kebijakan ini sangat berpengaruh pada peningkatan kebutuhan lahan sejak tahun 1989, yang telah berorientasi pada lokasi subur dan menguntungkan dari ketersediaan infrastruktur ekonomi.

2. Kebijakan pemerintah lainnya yang sangat berpengaruh terhadap perubahan fungsi lahan pertanian ialah kebijakan pembangunan permukiman skala besar dan kota baru. Akibat ikutan dari penerapan kebijakan ini ialah munculnya spekulan yang mendorong minat para petani menjual lahannya.

Sehingga terlihat bahwa sering sekali terjadi ketidakserasian antar kebijakan yang dikeluarkan pemerintah untuk mengatasi alih fungsi yang justru sering sekali justru meningkatkan laju alih fungsi lahan terutama lahan sawah.

\section{SIMPULAN DAN SARAN}

\section{Simpulan}

1. Peran Waduk Gajah Mungkur terhadap pertumbuhan sektor pertanian khususnya pada tahun irigasi teknik di Kecamatan Masaran Kabupaten Sragen sangat penting diantaranya mengatasi dampak dari kemarau panjang, meningkatkan produksi padi hal ini dikarenakan adanya perubahan pola tanam dalam satu tahun yaitu padi - padi palawijo, dan adakalanya diseling dengan tanaman tebu. Dalam hasil penelitian ditemukan adanya perbedaan yang signifikan hasil produksi padi sebelum dan sesudah menggunakan irigasi teknik.

2. Konversi lahan pertanian ke lahan non pertanian di Kecamatan Masaran Kabupaten Sragen tahun 2002 ke 2011 diketahui jenis penggunaan lahan yang meningkat cukup menonjol yaitu untuk industri menunjukkan 
angka $149 \mathrm{Ha}$ atau 3,38 \% dari konversi yang terjadi pada waktu tersebut, begitu juga perumahan 27,41 \%. Sedangkan yang berkurang sawah seluas 292 Ha dan tegalan seluas 19 Ha. Dampak yang terjadi akibat konversi lahan pertanian ke non pertanian di Kecamatan Masaran Kabupaten Sragen antara lain adanya degradasi daya dukung ketahanan pangan dan pendapatan pertanian menurun dan meningkatnya kemiskinan masyarakat.

\section{Saran}

1. Perlu dilakukan pengelolaan irigasi teknis secara adil sehingga tidak menimbulkan kecemburuan antar petani. Peningkatan jaringan irigasi yang akan membantu peningkatan pendapatan petani.

2. Perlu kebijakan pengendalian konversi lahan pertanian pada masa yang akan datang, tidak hanya pendekatan yuridis tertapi juga didukung pendekatan ekonomi dan sosial dengan menekan intensitas faktor ekonomi dan sosial yang dapat merangsang konversi lahan pertanian, mengendalikan luas, lokasi dan jenis lahan pertanian yang dikonversi dalam rangka menekan potensi dampak negatif yang ditimbulkan. Serta menetralisir dampak negatif konversi melalui kegiatan investasi yang melibatkan dana masyarakat terutama kalangan swasta pelaku konversi lahan. 


\section{DAFTAR PUSTAKA}

Ali Sofyan Husein, 1995. Ekonomi Politik Penguasaan Tanah. Pustaka Sinar Harapan, Jakarta

Augusman Harapan Padang, 2010. "Pengaruh Proyek Irigasi Pongkolen terhadap Pengembangan Wilayah Kecamatan Kerajaan Kabupaten Pakpak Bharat", Tesis, USU, Sumatra Utara.

Baliwati, YF. 2004. Pengantar Pangan dan Gizi, Cetakan I. Penerbit. Swadaya. Jakarta.

Boediono, 1999, Makro Ekonomi, BPFE. Yakarta.

Budi Trapsilo, 2010, "Irrigáis Bendungan Serbaguna Wonogiri dan Perubahasn Sosial Ekonomu Petani di Desa Jetak Kecamatan Sidoharjo Kabupaten Sragen Tahun 1987 - 2008”, Skripsi, Universitas Sebelas Maret, Surakarta.

Dimas Madang, 2010, “Analisis Peranan Sektor Pertanian Terhadap Perekonomian Jawa Tengah (Pendekatan Analisis Input - Output)", Tesis, UNDIP, Semarang.

Dinas Pertanian, Perkebunan dan Kehutanan Kabupaten Sragen, Program Penyuluhan Pertanian Kab. Sragen.

Gilarso, T. 2003. Pengantar Ilmu Ekonomi Bagian Makro. Kanisius. Yogyakarta.
Ilham, dkk, 2003. Perkembangan dan FaktorFaktor Yang Mempengaruhi Konversi. Lahan Sawah Serta Dampak Ekonominya. IPB Press. Jakarta.

Irawan, B. 2005. "Konversi Lahan Sawah : Potensi Dampak, Pola Pemanfaatannya, dan Faktor Determinan". Forum Penelitian Agro Ekonomi Vol 23, No 1, Juni 2005.

Kodoatie J. Robert, 2005, Pengantar Manajemen Infrastruktur, Edisi. Revisi, Pustaka Pelajar, Yogyakarta.

Krisnamurti, B. 2003, Penganekaragaman Pangan, Forum Kerja Penganekaragaman Pangan, Jakarta.

Mubyarto,1995, Pengantar Ekonomi Pertanian PT.Pustaka,LP3ES Indonesia,Anggota IKAPI, Jakarta.

Todaro, Michael. 2006, Economic Development, Erlangga, Jakarta

Wijanarko, Bambang, 2006, Evaluasi Sumber Daya Alam. 